\title{
Reading Comprehension Course Through a Genre- Oriented Approach at a School in Colombia
}

\section{Curso de lectura de pedagogía de géneros en un colegio de Colombia*}

\author{
Andrés Rodríguez Sánchez \\ agrodriguez@uninorte.edu.co \\ Universidad del Norte, Barranquilla, Colombia
}

This paper reports on an action-research study aimed at identifying the problems and needs of a specific group of tenth graders at a school in Colombia in relation to their reading comprehension in English in order to design, partially implement, and evaluate a genre-oriented syllabus. Findings show that the explicit instruction of metacognitive strategies helped students become more efficient readers, as well as the fact that the exposure and analysis of genres developed a better comprehension of different kinds of texts, making these students aware of the structure and patterns of the texts they were reading as they approached them with reading strategies that were appropriate for each genre and stage.

Key words: Genre approach, metacognitive instruction, reading comprehension, reading strategies, syllabus design.

Se reporta un estudio de investigación acción con el que se buscaba identificar los problemas y necesidades de un grupo de estudiantes en una escuela en Colombia, en cuanto a su comprensión lectora en inglés, con el fin de diseñar y parcialmente implementar un syllabus basado en la pedagogía de géneros. Los resultados muestran que la instrucción explícita de estrategias meta-cognitivas a los estudiantes, les ayudó a convertirse en lectores más eficientes. Asimismo, la exposición y el análisis de dife-

* $\quad$ Received: August 11, 2016. Accepted: January 19, 2017.

How to cite this article (APA 6th ed.):

Rodríguez Sánchez, A. (2017). Reading comprehension course through a genre-oriented approach at a school in Colombia. HOW, 24(2), 35-62. http://dx.doi.org/10.19183/how.24.2.331.

This article is licensed under a Creative Commons Attribution-NonCommercial-NoDerivatives 4.0 International License. License Deed can be consulted at http://creativecommons.org/licenses/by-nc-nd/4.0/. 
rentes géneros literarios, les permitió que adquirieran consciencia sobre la estructura y los patrones de los textos que leen, a medida que los abordaron con estrategias de lectura apropiadas para cada género.

Palabras clave: comprensión de lectura, estrategias de lectura, diseño de syllabus, instrucción meta-cognitiva, pedagogía de género.

\section{Introduction}

In order to understand the impact of this research, it is necessary to study the concept of reading comprehension and how it can be improved. Comprehension can be understood as a deep mental process in order to appreciate and recognize essential information within the text. But this concept goes further. Flavell (1985) defines comprehension in terms of the connection of the reader's prior knowledge and the text, which generates meaning. This means that comprehension is an internal process, but that should be activated through certain external developments that allow the readers to reach higher reading comprehension levels, which for this research, are referred to as the explicit metacognitive strategies.

This research was carried out in a local school in Barranquilla, Colombia, with a target group of 25 students in 10th grade, who were facing a lot of trouble comprehending different genres and types of texts in their English classes and therefore, they were showing poor performances and low levels of interest when doing reading tasks.

The main purpose of this research was to design a genre-oriented reading course, where learners would be provided with explicit strategy instruction and then determine how this would help them improve their comprehension when reading different types of texts in English, as well as to establish to what extent this would impact their motivation towards reading in English.

The following research question guided this inquiry: How does a reading class, focused on a genre-oriented syllabus and explicit metacognitive instruction, develop students' reading comprehension skills?

\section{Theoretical Considerations}

The genre-based approach has proved to be a successful mainstream method to teach English in Australia where teaching a second language is based on its principles. Its influence reaches across the world to the teaching of English in the UK. The key to the concept of genre is the "purpose" the piece of writing serves. This approach started with the Systemic Functional School of Linguistics inspired by the work of Halliday during the 1960s and 70s. During the last decades, research in this field has spread all over the world. 
Most of the research in this area related to writing around the world has been done by analysing the process of modelling, joint negotiation, and joint construction of different types of texts. However, there is also some research in other areas, such as the studies by Padilla de la Cerda (2013) and Herazo Rivera (2012), where the focus is on the topic of reading and speaking skills.

This research was carried out based upon different trends and theories in the reading comprehension area with the purpose of constructing a complete theoretical framework, which would work as a starting point for designing a genre oriented reading course, addressed to face the specific context needs and situational constraints.

Throughout years of research, there have been many findings which have led to various theories towards teaching reading without coming to a final agreement. Moorman and Ram (1994) stated that although much of the research has been carried out on teaching reading, "yet no theories exist which sufficiently describe and explain how people accomplish the complete task of reading real-world texts" (p. 16). Although there is not a perfect approach towards teaching reading comprehension, it is important that teachers have clarity about it and identify with one that represents their institutional principles, that better adjusts to their context and which meets their students' needs in order to address all the teaching decisions towards the same direction.

This paper provides various tenets related to how reading comprehension works in second language acquisition:

\section{Sociocultural Approaches to Language Learning}

Vygotsky (1934/1978) explains that "sociocultural approaches emphasize the concept that human activities take place in cultural contexts, and are mediated by language and other symbol systems" (p. 24). Specifically regarding the acquisition of language, sociocultural approaches consider that it is another example of a social source of development. ZukowGoldring and Ferko (1994) show the close relationship between promoting shared attention between beginning speakers and their caregivers and the emergence of the lexicon.

The sociocultural theory was essential for this project since from its viewpoint of learning, reading in itself implies a social interaction of learners within social contexts (Zukow-Goldring \& Ferko, 1994).

\section{Genre-Based Approach}

The genre-based approach can be defined as instructing students to read and write by using different genre texts, which were written for purposes other than for teaching reading within an English as a second/foreign language (ESL/EFL) context. 
In the case of this research, the emphasis is on reading; hence, this pedagogy considers reading as "a process with guidance through interaction, as the medium for acquiring control of genres, with a marginal to the central goal of learning to write for assessment." (Martin, 1999, p. 126)

As Swales (1990) states in his definition of genre: "A genre comprises a class of communicative events, which share some set of communicative purposes. These purposes are recognized by the expert members of the discourse community, and thereby constitute the rationale for the genre" (p. 58).

Specifically regarding the area of TEFL (teaching English as a foreign language), the approaches based on genre have not been a common practice. However, "there have been attempts to classify texts for reading purposes by appealing to a certain pragmatic or communicative function" (Baten \& Cornu, 1984, p. 198), suggesting a classification of texts according to their functional properties.

Another aspect suggested by Byram (2004), in relation to reading comprehension within TEFL, is the identification of the textual structure. It has been considered that

the influence of genre on text processing and comprehension, in which it is analysed how prior knowledge and familiarity with content and language may influence the comprehension of different genres, since it seems to influence the identification of the textual structure by allowing learners to anticipate the kind of information each text may contain. (p. 15)

This approach involves reading tasks of recognizing, predicting, and recalling patterns at each stratum of graphology, lexicon, grammar, and discourse. The methodology that has been developed to teach reading within the genre-based approach, and that this research considers the most appropriate to do so, is known as "learning to read: Reading to learn", moving the learner through a scaffolding interaction cycle of "prepare, task, and elaborate" (Rose, 2004).

\section{Reading as a Process and Stages of Reading}

"Reading comprehension is better regarded as an interactive process as well, rather than a particular outcome or product, through which a reader interacts with a text to construct meaning" (Cain, Oakhill, \& Bryant, 2004, p. 36). Hence, the meaning a reader derives from a text is influenced by the reader's own knowledge, experience, and purpose for reading.

This "interactive" process leads the reader to automaticity or reading fluency. Regarding the great influence in research and practice in TESOL of Krashen's (1982) hypotheses on language acquisition, and particularly the effect of "the schema theory" on studies dealing 
with reading comprehension, it is relevant to state the importance of the role of schemata in EFL/ESL reading comprehension, when understanding reading as a process.

Contemporary reading tasks involve three-phase procedures: pre-, while-, and postreading stages. Zhang (1993) briefs us that "comprehension is facilitated by explicitly introducing schemata through pre-reading activities" (p. 5). Similarly, Abraham (2002) states that an interactive approach "demands that the teachers activate the students' schema" during the pre-reading phase by helping "students recognize the knowledge that they already have about the topic of a text" (p. 5).

On the other hand, "the aim of [the] while-reading stage (or interactive process) is to develop students' ability in tackling texts by developing their linguistic and schematic knowledge ... many students report positively on the usefulness of while-reading activities" (Hedge, 2003, p. 17).

In the case of post-reading activities, Haller (2000) modelled "a number of activities which enhance learning comprehension through the use of matching exercises, cloze exercises, cut-up sentences, and comprehension questions" (pp. 21-24), among others.

Regarding the genre approach and with the purpose of achieving a better comprehension, teachers may implement a process of modelling, demonstrations, and guidance in which learners receive the appropriate support or scaffolding for them to be able to move forward independently in a later stage of the process, as well as to become more effective readers thanks to the autonomous application of reading strategies (Palincsar \& Brown, 1984).

\section{Reading Strategies}

Since reading is a thinking process and to help learners become effective readers, it is necessary to explicitly guide them through the correct scaffolding so they are able to select the most appropriate strategy until it becomes an unconscious process that will help them reconnect with the meaning of the text (Grabe, 1991).

A research project on second/foreign language (L2) conducted by Carrell (1985) demonstrated that explicit metacognitive strategy instruction for reading comprehension shows better results when compared to non-strategy instruction, showing the connection between students' learning styles and the effectiveness of training reading strategies.

"Research indicates that good readers of all ages engage in conscious, active comprehension strategies before, during, and after reading" (Pressley \& Wharton-McDonald, 1997, p. 453). Before reading, for instance, learners connect their goals and interests for reading and connect them with their previous knowledge about a topic and type of text. During reading, they understand important ideas and retrieve general and specific information 
from the text and try to resolve any comprehension difficulties they may encounter (Pressley \& Wharton-McDonald, 1997).

Regarding [the] genre-based approach, teachers must provide students with strategies to identify common discourse structures such as sequencing and cause/effect, and guide them through the use of graphic organizers to analyse the text, using higher order skills. This helps students learn to recognize the typical characteristics of various discourse frameworks and to use this knowledge strategically. (Williams, 2005, p. 14)

When using "authentic" texts, it is necessary to adapt them carefully, taking into consideration the topic, the type of text under analysis, and the most appropriate strategies students have learned in order to achieve a more successful process of genre analysis (Williams, 2005).

\section{Context and Participants}

This research was carried out with a group of 25 students in tenth grade at a private school in Barranquilla, Colombia, which has been in a bilingualism process for the last eight years. Their proficiency level in English was between B1 and B1.2, according to the Common European Framework of Reference (CEFR).

Regarding the English teachers, the staff consisted of 13 members; all of them had a bachelor degree in Modern Languages. The teacher researcher who was conducting this intervention holds a master degree in the arts of teaching English.

In relation to the context needs, the English teachers at the institution had no clarity over the approach towards teaching reading, since they considered the institutional approach and the guidelines of its theoretical framework very confusing due to the fact that the institution included a wide variety of concepts which seemed not to meet the context needs.

Regarding the methodologies used to develop reading skills in the institution, teachers' practices were very varied and did not work in service of a specific approach; hence, students' development in reading competences was a difficult aspect to be measured and validated as a logical product of coordinated teaching practice, which should have been embedded in a defined and clear understanding of the pedagogical approach towards teaching reading.

Hence, reading activities carried out in class were not coherent with a well-defined way of teaching reading, and did not meet the students' needs and different levels of proficiency and learning styles.

In relation to the reading proficiency level of the students, after the application of a reading proficiency test, it could be confirmed that it was a very heterogeneous group with 
different levels of proficiency, in which a representative quantity of them only reached the literal level of understanding, which made the comprehension of different texts as well as the interactions among students more difficult.

\section{Method}

Kemmis and McTaggart (1988) have stated that

Action research is a form of collective self-reflective enquiry undertaken by participants in social situations in order to improve the rationality and justice of their own social or educational practices, as well as their understanding of these practices and the situations in which these practices are carried out. (p. 5)

Regarding action research, Mertler (2009) stresses that "educators at a variety of levels have embraced it as something that makes conducting research a more 'manageable' task and that brings about results that are more informative and have immediate and direct application" (p. 4).

Taking into consideration the previous theoretical underpinnings, this project follows the "action research" methodology, since it intended not only to identify a problem within a specific context and carry out an analysis of the institutional teaching practices, but also to implement a well-structured intervention and finally verify its impact, to propose possible solutions to such problems. Hence, action research allows practitioners to address those concerns and make some change.

\section{Data Collection Procedure}

The data collection process of this research had two moments: One moment was the application of data collection techniques to construct the needs analysis and the other moment was related to the impact of the intervention, once the genre oriented reading course lessons were piloted.

The instruments applied to define the needs analysis were: a documentary analysis, a questionnaire with students, a reading proficiency test to determine the students' comprehension levels, and a class observation session before the intervention and one during the intervention. These instruments are explained as follows.

\section{Reading Proficiency Test}

The test was designed to determine the target group's level of proficiency in reading comprehension. It consisted of fifteen questions divided into sets of five questions, each setting assessing literal, inferential, and critical comprehension (see Appendix 1). 
The students were given a narrative text for them to read and answer open-ended questions in a period of 55 minutes. Each category (per level of comprehension) was assessed and analyzed separately. Results showed students had serious limitations towards identifying specific details in the text, as well as towards making inferences. A very limited amount of students were able to achieve a critical level of comprehension as shown in Table 1.

Table 1. Report on Reading Test Results

\begin{tabular}{|c|c|}
\hline $\begin{array}{c}\text { Number of students } \\
\text { (Percentage) }\end{array}$ & Level of reading competences \\
\hline $6 / 28(21 \%)$ & Critical comprehension \\
\hline $15 / 28(54 \%)$ & Inferential comprehension \\
\hline $7 / 28(25 \%)$ & Literal comprehension \\
\hline
\end{tabular}

This report informed the research in terms of the students' real level of comprehension, as well as for the design of materials with different sets of questions.

\section{Questionnaire for Students}

A questionnaire was designed to identify the students' perceptions towards some specific aspects related to reading comprehension, aspects such as the learning styles and interests towards reading, the types of materials they were commonly exposed to in contrast with the type of texts they would prefer to read, the methods and techniques they considered more effective and appealing when teachers taught reading comprehension, and the approach towards teaching reading, among others.

The results allowed this research a closer approach towards the students' perceptions, as well as to arrive at clear conclusions in order to structure the problem definition of the research. Table 2 shows the tendencies in quantitative results which led to more qualitative conclusions.

\section{Class Observation Session}

The class observation session was carried out with a volunteer professor who was teaching a reading class with the same target group. For this session, an observation template was designed (see Appendix 2), where some specific criteria were outlined for the observer to address the session within a specific framework. Aspects such as the objective of the class, the design and type of materials, mediations, types of activities and interactions, rapport and methodology, oriented the observation.

The observer marked the spaces provided to confirm his level of agreement or disagreement with each of the aspects that were observed, which served to arrive at quantitative results. On the other hand, a space was provided where the observer could write comments, which would allow this research effort to arrive at more profound conclusions. 
Table 2. Students' Questionnaire (Summarized Version)

\section{Learning styles, attitudes and students' preferences}

1. Before reading the texts in English class:
a. I look at the drawings: $67 \%$
b. I read the title and try to predict the reading: 15\%
c. I look at the end of the text to see how it ends: $0 \%$
d. I do nothing: $2 \%$
e. Other: $6 \%$

2. While I perform readings in English classes:
a. I look up unknown vocabulary: 8\%
b. I discuss with my partner about it: $71 \%$
c. I take notes about it: $2 \%$
d. I look at what my partner does and I take notes: 19\%

3. After the reading activities in English class:
a. I take notes on the most important aspects: $22 \%$
b. I talk to my partner(s) about what we read: $18 \%$
c. I perform the post-reading assigned task immediately: $60 \%$

\section{Reading materials}

4. What kind of English texts do you usually read outside the school?
a. Literature texts: 3\%
b. Authentic texts such as magazines, news, and Internet articles: 67\%
c. Specific texts for teaching English: 23\%
d. Other: $7 \%$

5. What kind of reading materials do you prefer to use in the English class?
a. Literature texts: $11 \%$
b. Authentic texts such as magazines, news, and Internet articles: 67\%
c. Specific texts for teaching English: 13\%
d. Other: $9 \%$ 
6. You think the reading texts used in the English class are:
a. Adjusted to your level: $16 \%$
b. Too easy for you. $0 \%$
c. Above my level: 35\%
d. Too difficult for you: $49 \%$

\section{Teaching methods and techniques}

7. After reading activities, what kind of post reading activities do you normally do:
a. Writing: $53 \%$
b. Speaking: $38 \%$
c. None: $0 \%$
d. Other: $9 \%$

8. What is your opinion of these post reading activities?

a. I liked them all or most of them: $77 \%$

b. I liked some: $18 \%$

c. I did not like any of them: 5\%

\section{The Needs Analysis}

The data collection process allowed this research to structure a contextual needs analysis.

The target needs could be defined in terms of the specific needs the learners had in relation to the main problem, as well as the lacks they had and what they wanted to achieve, so they could overcome the difficulties that were hindering their learning process when reading within the English class. (Rodríguez Sánchez, 2014, p. 36)

Especially when referring to their lack of reading strategies, which constituted the main aspect to address (see Table 3).

\section{The Pedagogical Proposal}

\section{Approaches to Course Design}

In this stage of the research, the main concern was to design a genre based reading course which could address all the efforts to improve the students' reading comprehension skills, as well as their critical reading skills, based upon clear theoretical concepts towards 
education, learning, and language. "This clarity allowed the definition of an intervention that would provide effective solutions to the main issues which were hindering the improvement in their reading skills" (Rodríguez Sánchez, 2014, p. 39).

Table 3. Contextual Needs Analysis

\begin{tabular}{|c|c|}
\hline Specific needs & Situational constraints \\
\hline $\begin{array}{l}\text { Necessities: } \\
\text { - Read, interpret, and perform tasks } \\
\text { of texts of different genres. } \\
\text { Lacks: } \\
\text { - Reading strategies to approach } \\
\text { different types of texts. } \\
\text { - Motivation towards reading } \\
\text { texts of different genres. } \\
\text { Wants: } \\
\text { - Interpret texts of different genres. } \\
\text { - Exchange insights about texts within a } \\
\text { real communication environment. }\end{array}$ & $\begin{array}{l}\text { - Different English proficiency levels of } \\
\text { the students within the same class. } \\
\text { - Students' lack of interest towards } \\
\text { texts of different genres. } \\
\text { - Textbook designed for native learners } \\
\text { of lower courses, hence topics which } \\
\text { student may find not relevant. } \\
\text { - Lack of clarity from the English } \\
\text { teachers about the institutional } \\
\text { approach and therefore about the } \\
\text { most suitable teaching practices, } \\
\text { especially in reading activities. } \\
\text { - Students' lack of reading strategies } \\
\text { towards different kinds of texts. }\end{array}$ \\
\hline
\end{tabular}

\section{Specific Needs and Course Approaches}

Table 4 shows the relation between the context needs and the approaches towards education, language and learning.

\section{Goals and Objectives of the Course}

Table 5 shows the relation between the target, learning, and human goal with the general objectives of the course.

\section{Syllabus Focus}

The syllabus focus that was considered the most suitable for the needs of this specific context was a genre-based syllabus which I considered better served to the accomplishment of our course objectives and goals. 
Table 4. Specific Needs and Approaches

\begin{tabular}{|c|c|}
\hline Specific needs & Course approaches \\
\hline $\begin{array}{l}\text { - Develop higher reading } \\
\text { comprehension levels. } \\
\text { - Interpret texts about different } \\
\text { genres and perform critical tasks. }\end{array}$ & $\begin{array}{l}\text { Approach to education: Hermeneutic approach } \\
\text { Students need to perform analytical and critical tasks } \\
\text { in which they develop their autonomy and construct } \\
\text { knowledge on the basis of previous knowledge. }\end{array}$ \\
\hline $\begin{array}{l}\text { - Analyze and discuss with } \\
\text { peers topics with diverse } \\
\text { communicative intentions, found } \\
\text { in texts of different genres. }\end{array}$ & $\begin{array}{l}\text { Approach to language: Functionalist approach } \\
\text { Students construct and negotiate meaning } \\
\text { based upon communicative activities } \\
\text { which foster interaction with peers. }\end{array}$ \\
\hline $\begin{array}{l}\text { - Socialize with peers about texts } \\
\text { insights, points of view and } \\
\text { propose solutions to problems. } \\
\text { - Analyze and apply reading } \\
\text { strategies to understand texts. }\end{array}$ & $\begin{array}{l}\text { Approach to learning: Sociocultural approach } \\
\text { There is a co-construction of knowledge regarding } \\
\text { the interaction of learners within cooperative tasks. } \\
\text { Cognitive approach } \\
\text { Students consciously construct knowledge by } \\
\text { using metacognitive strategies towards reading. }\end{array}$ \\
\hline
\end{tabular}

Table 5. Goals and Objectives

\begin{tabular}{|l|l|}
\hline \multicolumn{1}{|c|}{ Goals } & \multicolumn{1}{c|}{ General objectives } \\
\hline $\begin{array}{l}\text { Target: Development of } \\
\text { reading comprehension. }\end{array}$ & $\begin{array}{l}\text { Students should be able to read and } \\
\text { understand different types of texts at the } \\
\text { literal, inferential, and critical levels. }\end{array}$ \\
\hline $\begin{array}{l}\text { Learning: Development of reading } \\
\text { strategies towards different types of text. }\end{array}$ & $\begin{array}{l}\text { Students should be able to apply reading } \\
\text { strategies which allow them to interpret and } \\
\text { critically analyze different genres of texts. }\end{array}$ \\
\hline $\begin{array}{l}\text { Humanistic: } \text { Understand the importance } \\
\text { of respect for other points of view } \\
\text { when reading and analyzing a variety of } \\
\text { positions within different types of texts. }\end{array}$ & $\begin{array}{l}\text { Students should be able to exchange ideas } \\
\text { in relation to the texts under analysis within } \\
\text { an environment of respect and tolerance. }\end{array}$ \\
\hline
\end{tabular}

According to Hammond (2002), a genre-based syllabus provides the learners with the necessary base for critically reflecting and challenging hegemonic ${ }^{1}$ texts, which fosters students to become critical readers.

A hegemonic text is one that has the intention of stating positions as definite and that looks forward to maintaining the status quo. 
Particularly regarding the genre approach to teaching reading, genre analysts look for the common patterns of grammar usage, key vocabulary, and text structure and in particular text types (Bradford-Watts, 2003), aspects that I consider relevant to include in the syllabus of the course.

Specifically addressing the syllabus definition, one can say that genre-based approaches are able to draw together the best aspects of other syllabus models in order to provide the basis for a coherent, cohesive, and comprehensive framework for language teaching and learning (Feez, 1998).

From a systemic functional perspective, a syllabus founded on a genre-based approach provides activities which relate language choices to cultural purposes. Linguistic patterns are seen as pointing to contexts beyond the text itself, implying a range of social constraints and choices so that students are offered a way of seeing how different texts are created in distinct ways in terms of their purpose, audience, and message.

The main reasons for choosing this syllabus are explained in Table 6.

Table 6. Syllabus Focus

\begin{tabular}{|c|c|}
\hline Syllabus focus & Points for \\
\hline Genre-based syllabus & $\begin{array}{l}\text { - Analysis of texts of different genres. } \\
\text { - Identification of communicative intentions and } \\
\text { cultural contexts within different genres of texts. } \\
\text { - Promotion of social interaction through cooperative activities. }\end{array}$ \\
\hline
\end{tabular}

\section{Syllabus Sequence and Structure}

Sequence: Genre-based. The syllabus was sequenced according to the text types. The following text types were outlined: recounts (short stories), histories (biographies and autobiographies), and reports (news reports).

Structure: Matrix. This kind of syllabus structure includes a set of contents that is organized in a grid, in which the rows correspond to a particular text type (recounts - short stories) and the columns correspond to language aspects under analysis, communicative intention within the text type, suggested reading strategy, and the title of the text. This matrix is explained in more detail in Table 7. 
Table 7. Syllabus Matrix (Sample)

\begin{tabular}{|c|c|c|c|c|}
\hline $\begin{array}{c}\text { Text type/Genre/ } \\
\text { Structure }\end{array}$ & $\begin{array}{l}\text { Language } \\
\text { aspects }\end{array}$ & $\begin{array}{l}\text { Communicative } \\
\text { intention }\end{array}$ & Title & Reading strategy \\
\hline $\begin{array}{l}\text { Text type: Short stories. } \\
\text { Genre: Narrative } \\
\text { Structure: } \\
\text { Stages: Orientation, } \\
\text { complication, } \\
\text { and resolution } \\
\text { Phases: Setting, } \\
\text { description, episode, } \\
\text { problem, solution, etc. }\end{array}$ & $\begin{array}{l}\text { Particular } \\
\text { linguistic aspects } \\
\text { of short stories. } \\
\text { Example: } \\
\text { Past tense } \\
\text { of verbs. }\end{array}$ & $\begin{array}{l}\text { Particular } \\
\text { communicative } \\
\text { functions within } \\
\text { short stories }\end{array}$ & $\begin{array}{l}\text { "Girls" } \\
\text { by Gary } \\
\text { Paulsen }\end{array}$ & $\begin{array}{l}\text { Particular reading } \\
\text { strategies applicable } \\
\text { to short stories. } \\
\text { Before reading: } \\
\text { - Direct experience } \\
\text { - Drawing } \\
\text { inferences } \\
\text { - Summarizing }\end{array}$ \\
\hline
\end{tabular}

\section{Results From Piloting}

During the final stage of this research process, one unit (ten hours) of five sessions was piloted. A very detailed modelling phase was carried out, where the students had the chance to analyze the particular aspects of biographies and practice with different reading activities. Afterwards, a process of deconstruction of the text was carried out with the students so they could identify the linguistic and discourse aspects embedded in such texts, as well as to provide explicit instruction on reading strategies. This phase was followed by a joint construction, where the students reproduced this specific type of texts. Critical discussions closed the cycle, so students had the chance to socialize their points of view over the readings (see Appendix 3).

During one of these sessions, a new class observation was carried out in order to analyze the impact of the genre-oriented activities and the metacognitive instruction, and verify students' reactions and improvement in motivation towards reading in the English class.

The teacher who observed the class turned in his feedback with the purpose of gathering the final impressions and drawing definite conclusions over the real impact of the intervention. On the other hand, a group of six students were chosen in order to form a focus group in which students with whom the intervention was piloted shared some impressions about the impact of the genre oriented activities they took part in, and which evidenced a shift in their motivation towards reading and analyzing different types of texts and an improvement in their reading strategies application (see Appendix 4).

To be able to arrive at more concrete conclusions regarding the improvement of the learners' reading skills when using the genre oriented instruction and the explicit training on strategies, a final reading test was designed and applied to the students, which offered 
positive results in terms of literal and inferential understanding of the text, in comparison with the initial test they had taken before the intervention (see Appendix 5).

During and after the genre oriented instruction, a greater control over the different types of texts could be evidenced, a better understanding of its purpose and the development of a basic capacity to read various genres and write the same type of texts in a basic but more structured way. The application of reading strategies allowed the students to approach these texts more effectively, which made them feel more confident and entitled to continue reading other literature texts.

\section{Conclusions and Further Research}

During this final stage of the research, and regarding all the study process that ended with the intervention, it was possible to arrive at final conclusions where students' improvement in their reading comprehension level could be evidenced.

At the same time, learners showed a higher level of motivation and commitment towards reading different types of texts in English; furthermore, the institution was provided with a clear "genre-oriented reading course" for future analysis and adaptation in the curriculum.

But arriving at those conclusions was not an easy path. The whole process started with a data collection process to arrive at the problem definition. The problem definition was supported by the analysis of the school programs, questionnaires about students' perceptions of the phenomenon, observations of teachers' classes and a reading test. After applying this set of instruments, addressed to carry out a contextual needs analysis, the main aspects which were hindering students' reading comprehension of texts in English were identified, such as the fact that the students lacked metacognitive reading strategies since there was no explicit instruction in this area.

It was also identified that the institution and the teachers had no clarity over the approach that would work as the foundation of a reading course, so it could be concluded that it was necessary to design a course in which explicit instruction would be provided in relation to some specific genre-oriented underlying aspects, such as identifying every type of text structure, the grammar embedded in such texts, their particular discourse and lexicon, and communicative intentions, as well as defining an explicit instruction on reading strategies.

Afterwards, the piloting stage was designed in which a deep reflection of the lesson planning process was carried out. This allowed drawing well-structured sessions, where different types of texts were modelled by the teacher and analyzed by the students as in a scaffolding process. As a result, a three-unit syllabus focused on narrative texts such as short stories, recounts, biographies and autobiographies was designed to be partially piloted. 
Lastly, the piloting was implemented to verify the impact on students' reading comprehension skills after the intervention; only then, when final conclusions came to light, could the students' improvement in their reading comprehension and a perceived higher level of motivation and commitment towards reading tasks be evidenced.

This improvement was possible due to the fact that the students received explicit instructions to develop metacognitive skills regarding the application of the most efficient reading strategies according to the specific type of text under analysis, so students felt equipped with the tools to address texts more efficiently.

Secondly, the instructions included a detailed modelling stage in contrast with other types of texts; therefore, the students were able to identify the different types of texts structures by deconstructing them in their different phases, analyzing their particular linguistic aspects, as well as the fact that the students were familiarized with the particular discourse of different genres.

In the end, the fact of having made a careful balance of authentic and adapted materials that would meet the students' interests, the differentiated instruction regarding students with different levels of proficiency, and the spaces provided for the students to negotiate the curricula fostered an inclusive environment where the students felt encouraged to participate actively, read with a purpose, and state their positions over the topic under analysis, which definitely impacted positively their motivation towards the reading class.

\section{References}

Abraham, P. (2002). Skilled reading: Top-down, bottom-up. Field Notes, 10(2). Retrieved from http://www.sabes.org/sites/sabes.org/files/resources/fn102.pdf.

Baten, L., \& Cornu, A. M. (1984). Reading strategies for LSP texts: A theoretical outline on the basis of text function, with practical implications. In A. K. Pugh \& J. M. Ulijn (Eds.), Reading for professional purposes (pp. 190-201). London, UK: Heinemann.

Bradford-Watts, K. (2003). What is genre and why is it useful for language teachers? JALT Journal. Retrieved from http://jalt-publications.org/old_tlt/articles/2003/05/bradford_watts.

Byram, M. (Ed.). (2004). Routledge Encyclopedia of Language Teaching and Learning. London, UK: Routledge.

Cain, K., Oakhill, J., \& Bryant, P. (2004). Children's reading comprehension ability: Concurrent prediction by working memory, verbal ability, and component skills. Journal of Educational Psychology, 96(1), 31-42. http://doi.org/10.1037/0022-0663.96.1.31.

Carrell, P. L. (1985). Facilitating ESL reading by teaching text structure. TESOL Quarterly, 19(4), 727-752. http://doi.org/10.2307/3586673.

Feez, S. (1998). Text-based syllabus design. Sydney, AU: McQuarie University/AMES.

Flavell, J. H. (1985). Cognitive development. Englewood Cliffs, US: Prentice-Hall. 
Grabe, W. (1991). Current developments in second language reading research. TESOL Quarterly, 25(3), 375-406. http://doi.org/10.2307/3586977.

Haller, L. (2000). Modeling class activities for low-level literacy learners. Field Notes, 10(2). Retrieved from http://www.sabes.org/sites/sabes.org/files/resources/fn102.pdf.

Hammond, J. (Ed.). (2002). Scaffolding: Teaching and learning in language and literacy education. Newton, AU: Primary English Teaching Association.

Hedge, T. (2003). Teaching and learning in the language classroom. Oxford, UK: Oxford University Press.

Herazo Rivera, J. D. (2012). Using a genre-based approach to promote oral communication in the Colombian English classroom. Colombian Applied Linguistics Journal, 14(2), 109-125. http:// doi.org/10.14483/udistrital.jour.calj.2012.2.a07.

Kemmis, S., \& McTaggart, R. (1988). The action research planner. Victoria, AU: Deakin University Press.

Krashen, S. D. (1982). Principles and practice in second language acquisition. Los Angeles, US: University of Southern California.

Martin, J. R. (1999). Mentoring semogenesis: "Genre-based" literacy pedagogy. In F. Christie (Ed.), Pedagogy and the shaping of consciousness: Linguistic and social processes (pp. 123-155). London, UK: Continuum.

Mertler, C. A. (2009). Action research: Teachers as researchers in the classroom. Los Angeles, US: Sage Publications.

Moorman, K., \& Ram, A. (1994). Integrating creativity and reading: A functional approach. Proceedings of the Sixteenth Annual Conference of the Cognitive Science Society: Cognitive Science Program. Hillsdale, US: Lawrence Erlbaum Associates.

Padilla de la Cerda, F. (2013). The design of a theme-based and genre-oriented strategic reading course to improve students' reading comprehension skills at a public school in Colombia (Unpublished master's thesis). Universidad del Norte, Barranquilla, Colombia.

Palincsar, A. S., \& Brown, A. L. (1984). Reciprocal teaching of comprehension-fostering and comprehension-monitoring activities. Cognition and instruction, 1(2), 117-175. http://doi. org/10.1207/s1532690xci0102_1.

Pressley, M., \& Wharton-McDonald, R. (1997). Skilled comprehension and its development through instruction. School Psychology Review, 26(3), 448-466.

Rodríguez Sánchez, A. (2014). Improving reading comprehension through a genre based reading course (Unpublished master's thesis). Universidad del Norte, Barranquilla, Colombia.

Rose, D. (2004). Learning to read, reading to learn. Submission to the National Inquiry into the Teaching of Literacy 2005. Canberra, Australia. Department of Education, Science and Training.

Swales, J. M. (1990). Genre analysis: English in academic and research settings. Cambridge, UK: Cambridge University Press. 
Vygotsky, L. S. (1934/1978). Mind in society: The development of higher psychological processes (M. Cole, V. John-Steiner, S. Scribner, \& E. Souberman, Eds. \& Trans.). Cambridge, US: Harvard University Press.

Williams, J. P. (2005). Instruction in reading comprehension for primary-grade students: A focus on text structure. The Journal of Special Education, 39(1), 6-18. http://doi.org/10.1177/00224 669050390010201.

Zhang, Z. (1993). Literature review on reading strategy research. Retrieved from ERIC database (ED356643).

Zukow-Goldring, P., \& Ferko, K. R. (1994). An ecological approach to the emergence of the lexicon: Socializing attention. In V. John-Steiner, C. P. Panofsky, \& L. W. Smith (Eds.), Sociocultural approaches to language and literacy: An interactionist perspective (pp. 170-190). New York, US: Cambridge University Press. http://doi.org/10.1017/CBO9780511897047.008.

\section{The Author}

Andrés Rodríguez Sánchez holds an MA in English teaching (Universidad del Norte, Colombia). He currently serves as coordinator of basic undergraduate English courses and as a teacher of investigation processes of the MA at the Language Institute of Universidad del Norte. 


\section{Appendix 1: Reading Proficiency Test}

\section{Read the following text and then answer the questions below.}

\section{Kids' Sports 'Today}

In our wonderful past, kids gathered for pickup baseball games, throwing the football on the streets or just running into each other to throw the ball at the basketball court. Anyone could play. Parents watched or didn't. The point was to have fun. Some kids went on to play high-school sports, and that was it.

But now four-year-olds try out for the pee wee baseball league. Gym lessons begin at the age of three. Two-year-olds take soccer classes. Ridiculously, tennis camps enroll toddlers. By high-school, kids are so burnt out, lessoned out, and played out that they either drop out or fizzle out. Sports have become too competitive, and too many parents see their child as the next Tiger Woods, forcing their children to play or practice sports they do not like or are not good at, or simply are not prepared for meeting the level of demand.

Adapted from: "Elements of Literature" by Holt, Rinehart, and Winston (2009)

Now, give complete responses to the questions:

\section{Section 1: Literal comprehension}

1. What kind of games did kids play in the past?

2. What did parents do while the kids played?

3. In the past, what was the purpose of kids practicing sports?

4. What do four-year-olds try out for nowadays?

5. At what age do gym lessons start nowadays?

\section{Section 2: Inferential comprehension}

1. Why were sports for kids better in the past?

2. What is the impact of competitiveness in sports for kids? 
3. How different is the position of parents now from in the past in relation to their kids when they practice a sport?

4. What is the author's opinion about sports for kids at present?

5. Why do you think children end up burned out after practicing sports in competitive settings?

\section{Section 3: Critical Comprehension}

1. What is your opinion about children practicing competitive sports at a very early age?

2. What do you think must be the role of parents when the kids practice a sport?

3. What do you think is the best age for kids to start practicing a competitive sport and why?

4. What was your experience about practicing a sport as a kid?

5. Do you agree or disagree with the writer's point of view regarding the practice of sports of kids at early ages? Why? 


\section{Appendix 2: Class Observation}

\begin{tabular}{|c|c|c|c|c|c|}
\hline Criteria & $\begin{array}{l}\text { Totally } \\
\text { Agree }\end{array}$ & Agree & $\begin{array}{c}\text { Partially } \\
\text { agree }\end{array}$ & Disagree & Comments \\
\hline $\begin{array}{l}\text { The teacher states clear objectives } \\
\text { for the class and accomplishes } \\
\text { them successfully. }\end{array}$ & & & & & \\
\hline $\begin{array}{l}\text { The materials used in class are } \\
\text { clear and coherent with the } \\
\text { objectives of the class. }\end{array}$ & & & & & \\
\hline $\begin{array}{l}\text { The teacher's instruction used } \\
\text { in class corresponds with the } \\
\text { genre-oriented methodology. }\end{array}$ & & & & & \\
\hline $\begin{array}{l}\text { The teacher fosters participatory } \\
\text { activities which lead the students to } \\
\text { accomplish the class objectives. }\end{array}$ & & & & & \\
\hline $\begin{array}{l}\text { There are explicit instructions } \\
\text { on strategies. }\end{array}$ & & & & & \\
\hline $\begin{array}{l}\text { There is a reading comprehension } \\
\text { set of skills based on the modelling } \\
\text { and deconstruction of structural } \\
\text { aspects of different types of texts. }\end{array}$ & & & & & \\
\hline $\begin{array}{l}\text { There is a stage for reading } \\
\text { comprehension skills based on } \\
\text { the modelling, practice, and } \\
\text { application of grammar aspects } \\
\text { related to each type of text. }\end{array}$ & & & & & \\
\hline $\begin{array}{l}\text { Students' advances in their critical } \\
\text { comprehension of texts are evident. }\end{array}$ & & & & & \\
\hline $\begin{array}{l}\text { The teacher provides effective } \\
\text { feedback to the students. }\end{array}$ & & & & & \\
\hline
\end{tabular}


Appendix 3: Designed Materials (Sample Class)

\begin{tabular}{|c|c|}
\hline \multicolumn{2}{|c|}{ Reading Strategies } \\
\hline Specific strategy & Students' action \\
\hline $\begin{array}{l}\text { Before reading: } \\
\text { Prediction strategy to activate students' prior } \\
\text { knowledge from readings titles and pictures. }\end{array}$ & $\begin{array}{l}\text { Try to predict from the picture and the } \\
\text { title what the text is going to be about. }\end{array}$ \\
\hline $\begin{array}{l}\text { While reading: } \\
\text { Confirming predictions during reading. } \\
\text { Making inferences. }\end{array}$ & $\begin{array}{l}\text { Confirm your predictions while you read. } \\
\text { Try to read beyond the lines and } \\
\text { interpret some specific aspects. }\end{array}$ \\
\hline $\begin{array}{l}\text { After reading: } \\
\text { Identify some generalities about the writer's } \\
\text { intention or purpose, try to interpret his/ } \\
\text { her ideology, and identify bias within } \\
\text { the text and state their positions. }\end{array}$ & $\begin{array}{l}\text { Identify the following aspects: } \\
\text { a. What and who is the text about? } \\
\text { b. How is the message within the text conveyed? } \\
\text { (style, fiction, nonfiction, facts, opinions, } \\
\text { emotions, etc.) } \\
\text { c. Who is the target audience? (addressed to a specific } \\
\text { audience, age, social status, race, etc.) } \\
\text { d. What is the purpose of saying what is in the text? } \\
\text { (authors intention like informing, entertaining, } \\
\text { stating a position, persuading, etc.) } \\
\text { e. What was the social reality in that moment? } \\
\text { f. How did his stay in jail help him in his cause? }\end{array}$ \\
\hline
\end{tabular}

\section{Modeling Text Structure}

Read the following biography about Nelson Mandela and check how this type of text is divided into three stages: 


\begin{tabular}{|l|l|}
\hline \multicolumn{2}{|c|}{ Nelson Mandela's Biography } \\
\hline \multicolumn{1}{|c|}{ Stage } & \multicolumn{1}{c|}{ Part of the text } \\
\hline $\begin{array}{l}\text { Orientation: provides the reader with } \\
\text { background information needed to } \\
\text { understand the text, e.g., who, when, where. }\end{array}$ & $\begin{array}{l}\text { Rolihlahla Mandela was born into the Madiba } \\
\text { clan in the village of Mvezo, Transkei, on 18 } \\
\text { July 1918. His mother was Nonqaphi Nosekeni } \\
\text { and his father was Nkosi Mphakanyiswa } \\
\text { Gadla Mandela, principal counsellor to } \\
\text { the Acting King of the Thembu people, } \\
\text { Jongintaba Dalindyebo. In 1930... }\end{array}$ \\
\hline $\begin{array}{l}\text { Sequence of events: series of events } \\
\text { typically ordered chronologically. }\end{array}$ & $\begin{array}{l}\text { Mandela, while increasingly politically involved } \\
\text { from 1942, only joined the African National } \\
\text { Congress in 1944 when he helped to form } \\
\text { the ANC Youth League (ANCYL). } \\
\text { In 1944, he married Walter Sisulu's cousin, } \\
\text { Evelyn Mase, a nurse. They had two } \\
\text { sons, Madiba Thembekile "Thembi" and } \\
\text { Makgatho, and two daughters both called } \\
\text { Makaziwe, the first of whom died in infancy. } \\
\text { He and his wife divorced in 1958... }\end{array}$ \\
\hline $\begin{array}{l}\text { Re-orientation: rounds off the sequence } \\
\text { a summary statement/an evaluative } \\
\text { comment/a return to the starting point. }\end{array}$ & $\begin{array}{l}\text { There were several times during the process } \\
\text { where violence threatened to break out. } \\
\text { Nelson was a strong force in keeping the } \\
\text { calm and preventing a major civil war. } \\
\text { Adapted from: https:/ / www.nelsonmandela. } \\
\text { org/content/page/ biography }\end{array}$ \\
\hline
\end{tabular}

\section{Language and Lexical Aspects}

Read the text again and check out the adjectives which describe the main character. Also check the verbs that express past actions:

Now choose five verbs from the text and construct complete sentences about yourself: Example: I attended school last week.

1.

2.

3.

4.

5. 
Andrés Rodríguez Sánchez

Now choose three adjectives from the text you consider are qualities of a hero and construct complete sentences:

Example: Peter is a strong man.

1.

2.

3. 


\section{Appendix 4: Focus Group}

\section{General Questions}

1. What do you think about the genre oriented activities?

2. What do you like about them? What don't you like? Why?

3. Do you think "genre based" is a better way to teach English in school? Why / Why not?

4. Would the rest of the students feel more motivated to study English this way, better that the traditional way?

\section{Specific Questions}

1. Was there something that caught your attention the most?

2. What would you change? Why?

3. Which activities helped you achieve a better comprehension of the texts you read?

4. How did you feel about analysing different types of texts? 


\section{Appendix 5: Final Reading Test}

\section{A. Read the following text.}

\section{Healthy Lifestyle}

(1) When I was at school, I played some football and rugby. I hated rugby because I couldn't catch the ball, but I enjoyed football. I started out being a terrible player and nobody wanted me to be on their team. But I started to improve slowly and, after a few years, the other kids in the school accepted me as a player, not a fantastic one, but one who wouldn't do anything stupid.

(2) When I was at university, I stopped playing sports altogether. I was working too hard, started eating too much, and, worst of all, I started smoking. By the time I was thirty, I was overweight and unfit.

(3) Then one day, I was sitting in the park, smoking a cigarette. I was watching these guys running. They looked slim, fit and healthy, and some of them were much older than me. When I got home, I looked in the bathroom mirror and, well, I suppose I just didn't like what I saw. At that moment, I decided to stop smoking and change my life. I went to a sports shop, bought myself a pair of running shoes, shorts, and a sweatshirt. That evening I went running around the park-for ten minutes! Physically, I felt terrible. Everything was hurting: my legs, my chest. But inside, I felt good about it.

(4) The next evening, I went again. I still only did ten minutes, but I didn't feel as bad as I did the day before. Within a week, I was running for fifteen minutes, then twenty, and after three weeks I ran for thirty minutes without stopping. Quite soon, I was running longer distances and my speed and strength were improving all the time. After six months, I was a runner! That was five years ago. I now run eight kilometres six times a week and love it. My proudest moment was last year, when I ran my first marathon and finished in around three hours. I'm fitter now than I've ever been, and am so glad that I went to sit in the park that day five years ago.

B. Read for main ideas. Read the four sentences below. Four of them describe the main idea of a paragraph in the reading passage. Write the paragraph number next to the sentence that best describes the main idea. You will not use one option.

1. How he got fit again and how he feels about it. 
2. His lifestyle and performance as a sportsman at school.

3. The reason he liked playing football.

4. The reason he started getting fit again.

5. His unhealthy lifestyle when he began university.

C. Read for details (multiple choice). Read the following statements and choose the best option to complete them.

1. He hated rugby because...
a. nobody wanted him to play.
b. he was very slow and short.
c. he wasn't good for catching the ball.

2. He bought a pair of running shoes because...
a. he wanted to start running and get fit again.
b. he liked the other guys' running shoes.
c. his running shoes were old already.

3. The second time he went running, he did it for...
a. ten minutes.
b. fifteen minutes.
c. twenty minutes.

4. He started running...
a. six months ago.
b. five years ago.
c. one year ago.

D. Read for details. Provide short answers to the following questions:

1. Which sport did he like best at school?

2. Why did nobody want to play with him at first?

3. Where was he when he decided to change his lifestyle?

4. How often does he run now? 
5. What did he do last year?

E. Making inferences. Read the following statements. Circle the option of the inference that can be made from each statement.

1. "Everything was hurting: my legs, my chest. But inside, I felt good about it." He felt good about it because...
a. he was not tired.
b. it was a good start toward getting fit.
c. he didn't feel sick anymore.

2. "I looked in the bathroom mirror and, well, I suppose I just didn't like what I saw." He didn't like what he saw because...
a. he looked very tired.
b. he looked old and unfit.
c. he looked sick.

3. "I am so glad that I went to sit in the park that day five years ago." He was glad because...
a. it motivated him to start running.
b. he did not like what he saw.
c. it was the first time he ran a marathon.

Adapted from http://www.dsw.edu.pl/fileadmin/user_upload/SJO/pliki/English_Language_ Exam_-_A2-B1.pdf 